University of Nebraska - Lincoln

DigitalCommons@University of Nebraska - Lincoln

Roman L. Hruska U.S. Meat Animal Research

U.S. Department of Agriculture: Agricultural Center

Research Service, Lincoln, Nebraska

1985

Sex, Age, and Breed Related Changes in Bovine Testosterone and Intramuscular Collagen

\author{
H. Russell Cross \\ Texas A \& M University \\ Bruce D. Schanbacher \\ U.S. Meat Animal Research Center \\ John D. Crouse \\ U.S. Meat Animal Research Center
}

Follow this and additional works at: https://digitalcommons.unl.edu/hruskareports

Part of the Animal Sciences Commons

Cross, H. Russell; Schanbacher, Bruce D.; and Crouse, John D., "Sex, Age, and Breed Related Changes in Bovine Testosterone and Intramuscular Collagen" (1985). Roman L. Hruska U.S. Meat Animal Research Center. 63.

https://digitalcommons.unl.edu/hruskareports/63

This Article is brought to you for free and open access by the U.S. Department of Agriculture: Agricultural Research Service, Lincoln, Nebraska at DigitalCommons@University of Nebraska - Lincoln. It has been accepted for inclusion in Roman L. Hruska U.S. Meat Animal Research Center by an authorized administrator of DigitalCommons@University of Nebraska - Lincoln. 


\section{Sex, Age, and Breed Related Changes in Bovine Testosterone and Intramuscular Collagen}

H. Russell Cross, Bruce D. Schanbacher, and John D. Crouse'

\section{Introduction}

Castration of the male in meat-producing animals has long been a traditional practice in the production of commercial livestock. Numerous research studies have indicated that intact bovine males grow more rapidly, utilize feed more efficiently, and produce a higher yielding carcass than castrates. Even though young bulls have obvious growth and leanness advantages over steers, their meat is usually lower and more variable in tenderness than steers. These differences in tenderness have been attributed to differences in fatness or differences in connective tissue.

Factors influencing the amount and strength of intramuscular collagen have been linked to animal age, sex, and breed. The literature strongly indicates that collagen solubility decreases significantly with animal age and that most of these changes take place from birth to about 2 years of age. Results have illustrated that the age-related changes in tenderness are significantly more pronounced in bulls than in steers and heifers, particularly in muscles high in collagen. These findings suggest that age-related changes in the cross-linking of collagen might be related to the sex of the animals.

Several workers reported an increase in collagen content in young bulls at about 12 months of age. Others have suggested that the increase in collagen content at this age, which was accompanied by an increased solubility, was due to an increase in collagen synthesis related to the hormonal changes occurring during puberty in young bulls.

The objective of this phase of our research was to investigate the influence of animal age, breed, and sex condition (bull vs steer) on the content and solubility of intramuscular collagen using muscle biopsies in the longissimus muscle.

\section{Procedure}

Selection and management of animals. Twenty bulls and twenty steers representing four breeds ( $7 / 8$ Charolais, $7 / 8 \mathrm{Sim}$ mental, Hereford, and Angus), were randomly selected for this study. At 5 months of age, the animals were placed on a ration of 78 percent corn silage (IFN 3-08-153), 10 percent corn (IFN 4-02-931), and 12 percent supplement. Rations varied as the animals matured with the final ration being 42.7 percent corn silage, 54.1 percent corn, and 3.2 percent supplement.

Muscle and blood samples. Muscle biopsy samples (approximately $10 \mathrm{~g}$ ) from the ribeye muscle of each animal were obtained at $6,9,12,15$, and 18 months of age. Sampling began in the posterior portion of the muscle and continued on alternate sides to the 13th rib area. One week prior to each biopsy, blood samples were collected from each bull and steer. Serum was harvested from the blood samples and assayed for testosterone concentration.

\section{Results}

Breed effects. The influence of breed on collagen and testosterone levels is presented in Table 1. Even though total and insoluble collagen values were not significantly influenced by breed, soluble collagen and testosterone levels were. Percentage soluble collagen and testosterone were highest in the Simmental cattle, while testosterone was lowest in the Hereford cattle.

\footnotetext{
${ }^{1}$ Cross is a professor of animal science, Texas A\&M University (formerly research leader, Meats Unit, MARC); Schanbacher is a reproductive physiologist, Reproduction Unit; and Crouse is the research leader, Meats Unit, MARC.
}

Sex effects. Sex (bull vs steer) had significant effects on a i collagen traits (Table 2). When age and breeds were combinec, the longissimus from bulls contained more soluble collage 1 and less total collagen. The magnitudes of the difference : presented in Table 2 were not large but were significant.

Age effects. Data reported in Table 3 indicate that collage ? solubility decreases with age. Also of interest in Table 3 is th : relationship between total collagen and testosterone. Total $\mathrm{cc}$ lagen increased up to 12 months of age and then decrease significantly. The same trend was apparent for testosterone

Age/sex relationships. Even though the age/sex interactic was not significant, the means are presented in Table 4 to giv a clearer picture of the sex/age relationship. Total collage increased to 12 months and then decreased in both bulls ar steers. The obvious question is: Why the increase in collage in steers when the testosterone levels were not affected $k$ y age? As expected, the soluble collagen decreased as as increased. The magnitude of the decrease was much less bulls, particularly at 12 months. This could perhaps indica $\varepsilon$ some endocrine influence above and beyond the influence of testosterone.

Data presented add further support to the age effects c $\mathrm{I}$ collagen cross-linking and collagen solubility. Results also $\mathrm{r}$ veal an interesting relationship between collagen synthesis ar $c$ possible endocrine influences. These differences also appe to be influenced by breed. Other workers have reported in increase in intramuscular collagen content in bulls at 12 montl s of age. It appears from the present and other investigation 3 that, for bulls, the collagen content increases near puberty.

The increased collagen synthesis near puberty would res $t$ in an increase in the proportion of immature collagen, le ; cross-linking, and, thus a greater proportion of collagen th t would be solubilized during cooking. Since these bulls wou d probably be marketed at a later age (14 to 16 months), th ? cross-linking would be expected to continue, and the to al amount of cross-linked (toughened) collagen would also ba higher in bulls. The impact of this increase on tenderness $v$ ill require further study, but one could hypothesize that this s: uation could be a significant contributor to the toughness in bulls.

In conclusion, the data from this study indicate that bulls a ' $\theta$ different from steers in regard to relative synthesis of intr :muscular collagen at or near puberty. The increased synthe is of collagen appears to be influenced by testosterone or sor 19 related endocrine parameter. The mechanism of this acti nn remains unclear.

Table 1.-The influence of breed on mean collage $\pi$ and testosterone traits

\begin{tabular}{|c|c|c|c|c|}
\hline Breed & $n$ & $\begin{array}{c}\text { Total } \\
\text { collagen } \\
\text { (mg/g) }\end{array}$ & $\begin{array}{c}\text { Soluble } \\
\text { collagen } \\
\text { (pct) }\end{array}$ & $\begin{array}{c}\text { Testosterc } \\
(\mathrm{ng} / \mathrm{ml})\end{array}$ \\
\hline Simmental ....... & 10 & 4.97 & 16.99 & 5.21 \\
\hline Charolais ........ & 10 & 5.73 & 14.87 & 4.31 \\
\hline Hereford......... & 10 & 5.24 & 15.06 & 2.90 \\
\hline Angus $\ldots \ldots \ldots$. & 10 & 5.66 & 14.43 & 4.97 \\
\hline
\end{tabular}


lable 2.-The influence of sex on mean collagen content in the longissimus

\begin{tabular}{|c|c|c|}
\hline$x$ & $\begin{array}{c}\text { Total collagen } \\
(\mathrm{mg} / \mathrm{g})\end{array}$ & $\begin{array}{c}\text { Soluble collagen } \\
\text { (pct) }\end{array}$ \\
\hline 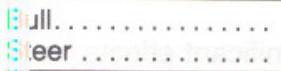 & $\begin{array}{l}5.75 \\
5.05\end{array}$ & $\begin{array}{l}15.92 \\
14.76\end{array}$ \\
\hline
\end{tabular}

Table 3.-The influence of age on meat collagen and testosterone traits (bulls and steers combined)

\begin{tabular}{|c|c|c|c|}
\hline $\begin{array}{c}\text { A imal } \\
\text { ge } \\
\text { no) }\end{array}$ & $\begin{array}{c}\text { Total collagen } \\
(\mathrm{mg} / \mathrm{g})\end{array}$ & $\begin{array}{c}\text { Soluble collagen } \\
\text { (pct) }\end{array}$ & $\begin{array}{c}\text { Testosterone } \\
\text { (ng/ml) }\end{array}$ \\
\hline 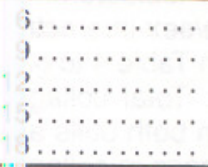 & $\begin{array}{l}3.89 \\
4.74 \\
8.91 \\
5.39 \\
4.06\end{array}$ & $\begin{array}{r}19.26 \\
20.73 \\
14.83 \\
11.94 \\
9.93\end{array}$ & $\begin{array}{l}2.22 \\
2.95 \\
9.09 \\
3.13 \\
\cdots\end{array}$ \\
\hline
\end{tabular}

\begin{tabular}{|c|c|c|c|c|}
\hline \multirow{2}{*}{$\begin{array}{r}A \text { imal } \\
\mathrm{je} \\
\ldots \mathrm{no}) \\
\end{array}$} & \multicolumn{2}{|c|}{ Soluble collagen (pct) } & \multicolumn{2}{|c|}{ Total collagen (mg/g) } \\
\hline & Bull & Steer & Bull & Steer \\
\hline i.......... & 19.63 & 18.88 & 4.03 & 3.75 \\
\hline $9 .$. & 21.61 & 19.86 & 4.89 & 4.58 \\
\hline $1 \ldots$ & 16.74 & 12.91 & 9.99 & 7.83 \\
\hline$i \ldots \ldots \ldots$ & 11.58 & 12.30 & 5.36 & 5.42 \\
\hline $3 \ldots \ldots \ldots$ & 10.04 & 9.83 & 4.49 & 3.64 \\
\hline
\end{tabular}

